\title{
Choice of mathematics research papers themes by senior high school students-members of MAS in application aspect
}

\author{
Skotnikova L.* \\ Kremenchuk Mykhailo Ostrohradskyi National University, Kremenchuk, Ukraine
}

Received: $05.10 .2019 \quad$ Accepted: 22.12 .2019

\begin{abstract}
The purpose of the paper is to study problems of the mathematics research projects theme choice and discourse by senior high school students-members of Ukraine Minor Academy of Sciences (MAS). It is shown that the mathematical theory allows a new scientific level to explore and solve complex technical, physico-chemical, engineering, biotechnology and other problems of our time. The advantages of the project themes choice of in the application aspect are investigated. The method of research works themes definition and choice by MAS studentsmembers with involvement of education stakeholders in joint activity with a mathematics teacher is resulted. The scheme of MAS students-members' mathematical and research abilities development with active involvement of stakeholders model is presented. The science novelty is that the effectiveness of an extracurricular research work in mathematics organization to improve the choice of work themes in application aspect investigated and analyzed. The article analyzes works content of the Department of mathematics presented at the competitions of MAS during 20172019. It is revealed that content of MAS students-members is aimed only at in-depth study of individual sections of mathematics school course, and fixing the skills of solving problems of increased complexity, but there are not enough works of an applied nature that demonstrate some practical applications of mathematical methods. It is concluded what themes and why should be in demand by MAS students-members in the next competitions of research projects.
\end{abstract}

Key words: research project, research paper theme, Minor Academy of Sciences, education stakeholder.

\section{Вибір тем науково-дослідницьких робіт з математики учнями-членами МАН в аспекті прикладного застосування}

\author{
Скотнікова Л. М. \\ Кременчуцький національний університет імені Михайла Остроградського, Кременчук, Україна
}

\begin{abstract}
Анотація. У статті розглянуто проблему вибору й обґрунтування тем науково-дослідницьких проектів 3 математики учнів-членів Малої академії наук України. Показано, що математична теорія дозволяє на новому науковому рівні досліджувати й розв'язувати складні технічні, фізико-хімічні, інженерні, біотехнологічні та інші завдання сучасності.. Досліджено переваги вибору тем проектів в аспекті прикладного застосування. Наведено спосіб визначення і вибору тем науково-дослідницьких робіт учнями-членами МАН із залученням стейкхолдерів освіти в спільній з учителем діяльності. Репрезентовано схему моделі розвитку математичних та дослідницьких здібностей учнів-членів МАН із активним залученням стейкхолдерів. У статті проаналізовано змісту тем робіт відділення математики, представлених на конкурсах МАН протягом 2017-2019 років. Виявлено, що зміст тем учнів-членів МАН спрямований лише на поглиблене вивчення окремих розділів шкільного курсу математики, закріплення навичок розв'язання задач підвищеної складності, натомість бракує робіт прикладного характеру, що демонструють практичне застосування математичних методів. Зроблено висновок про те, які теми і чому мають бути затребувані учнями-членами МАН у наступних конкурсах науководослідницьких робіт.
\end{abstract}

Ключові слова: науково-дослідницький проект, тема науково-дослідницької роботи, Мала академія наук, стейкхолдер освіти.

\footnotetext{
Corresponding Author: Skotnikova Ludmyla Mykolaivna.+38(05366)31147. E-mail: Iskotnikova7@gmail.com. Kremenchuk Mykhailo Ostrohradskyi National University,

Pershotravneva st, 20, Kremenchuk, Ukraine, 39600.

Відповідальний автор: Скотнікова Людмила Миколаївна. +38(05366)31147. E-mail: Iskotnikova7@gmail.com. Кременчуцький національний університет імені Михайла Остроградського, вул. Першотравнева, 20, м. Кременчук, Україна, 39600.
} 


\title{
Выбор тем научно-исследовательских работ по математике учениками- членами МАН в аспекте прикладного применения
}

\author{
Скотникова Л. М.
}

Кременчугский национальный университет имени Михаила Остроградского, Кременчуг, Украина

\begin{abstract}
Аннотация. В статье рассмотрена проблема выбора и обоснования тем научно-исследовательских проектов по математике учеников-членов Малой академии наук Украины. Показано, что математическая теория позволяет на новом научном уровне исследовать и решать сложные технические, физико-химические, инженерные, биотехнологические и другие задачи современности. Исследованы преимущества выбора тем проектов в аспекте прикладного применения. Приведен способ определения и выбора тем научноисследовательских работ учениками-членами МАН с привлечением стейкхолдеров образования в совместной деятельности с учителем. Представлена схема модели развития математических и исследовательских способностей учащихся-членов МАН при активном привлечении стейкхолдеров. В статье проанализировано содержание тем работ отделения математики, представленных на конкурсах МАН в течение 2017-2019 годов. Выявлено, что содержание тем учеников-членов МАН направлено лишь на углубленное изучение отдельных разделов школьного курса математики, закрепление навыков решения задач повышенной сложности, зато недостает работ прикладного характера, демонстрирующих практическое применение математических методов. Сделан вывод о том, какие темы и почему должны быть востребованы учениками-членами МАН в последующих конкурсах научно-исследовательских работ.

Ключевые слова: научно-исследовательский проект, тема научно-исследовательской работы, Малая академия наук, стейкхолдеры образования.
\end{abstract}

\section{Bcmyn}

Останні десятиліття в українській позашкільній освіті дуже актуальним є питання організації науково-дослідної діяльності на всіх рівнях. Дослідна діяльність учнів - це творча пізнавальна діяльність, спрямована на відкриття суб'єктивно нового знання, способу дій, що виконується за різним ступенем самостійності, зумовленим віковими особливостями та рівнем володіння науководослідницькими уміннями.

Для виявлення та підтримки обдарованих учнів, залучення їх до науково-дослідної та експериментальної роботи, в Україні функціонує Мала академія наук (МАН), у якій діють різні за своїми напрямками гуртки. Математичний гурток - це завжди особлива атмосфера, неповторний світ, культура, де панують роздуми, сумніви, міркування, осмисленість, повага до думки. Користь від науково-дослідної роботи в математичних гуртках незаперечна - наприклад, за допомогою незвичайних застосувань добре описаних і доведених формул і учні-члени МАН легко і швидко розв'язують завдання зовнішнього незалежного оцінювання з математики й численних математичних конкурсів, турнірів, змагань, що відбуваються в Україні.

Математична складова навчання посідає особливе місце, адже математика є однією з провідних фундаментальних дисциплін, яка не лише відіграє важливу роль як засіб формування абстрактного логічного мислення, а й має велике прикладне значення, оскільки створює теоретичну базу для подальшої професійної діяльності [1]. Як і всі інші науки, математика виникла з практичної потреби людей. Цілі відділи математики створюються для аналізу явищ природи і для вирішення технічних завдань [2]. Проте часто буває, що на запитання або низку запитань, які ставляться виробництвом, може й не бути відповіді з об'єктивних причин. Вони полягають у відсутності людських знань, необхідних для розв'язання певних завдань. У цьому випадку виникає проблема (від гр. problema - складність, перешкода). Виникнення та вирішення проблем $є$ природним процесом, пов'язаним із необхідністю постійного отримання нових знань, що потрібні для розв'язання конкретних питань матеріального виробництва. Науковою проблемою називають сукупність складних завдань, у яких сформульовані основні теоретичні та практичні питання, що потребують вивчення, дослідження та вирішення. Постановка проблеми передбачає організацію дослідження, кінцевою метою якого є розробка нової закономірності, необхідної для побудови методик вирішення певних завдань [3]. 
Отже, постановка математичних проблем, вибір і обґрунтування тем науково-дослідницьких проектів учнів-членів МАН $є$ актуальними і набувають значення в аспекті прикладного застосування математичних знань.

Загальні питання організації позакласної науково-дослідної роботи учнів розглядають як вітчизняні вчені (О. Шидакова-Каменюка, О. Самохвалова, С. Олійник і О. Кравченко [3], О. Балакірева i P. Левін [4]), так і зарубіжні дослідники й практики (M. Stohlmann [5], R. Mohd Rustam i K. Azlina [6], F. Jensen i J. Sjaastad [7], A. Leung [8], A. Weinberg i L. McMeeking [9], K.-Ch. Yu, P.-H. Wu, S.-Ch. Fan [10], A. Bicer i R. Capraro [11], J. H. Ling Koh [12], Y. Tas, G. Aksoy, E. Cengiz [13], R. Sinicrope, M. Eppler, R. Preston i M. Ironsmith [14], D. Polly, M. Mraz, R. Algozzine [15]). Актуальним проблемам науководослідницької роботи з математики присвячені праці І. Хівріч [2], Д. Васильєвої [16]. Вагомий внесок у дослідження проектної діяльності учнів-членів МАН, зокрема розробки науково-дослідницьких проектів, внесли І. Добровольска [17] і М. Пихтар [18].

Незважаючи на гостроту проблеми, аналіз інформаційних джерел показує, що бракує публікацій щодо вибору і обґрунтування тем науково-дослідницьких робіт з математики учнів-членів МАН.

Дослідження видатних вчених-математиків XX-XXI століть значно розвинули загальну математичну теорію, що дозволяє на новому науковому рівні досліджувати й розв'язувати складні технічні, ффізико-хімічні, інженерні, біотехнологічні та інші завдання сучасності. Проте дотепер вибір і обґрунтування тем учнями-членами МАН були спрямовані лише на поглиблене вивчення окремих розділів шкільного курсу математики, закріплення навичок розв'язання задач підвищеної складності.

Зазначені недоліки організації науково-дослідницької роботи 3 математики призводять до зниження мотивації учнів під час вибору професій, пов'язаних із науковими дослідженнями, що потребують активного застосування математичного апарату. Така ситуація вже виникала в історії математичної науки у давнину.

Давньогрецькі математики хотіли дати всім поняттям, які вони описували математично, геометричну інтерпретацію. Внаслідок цього в алгебрі на довгі часи настав період «застою». Відкриття несумірних відрізків, негативних й ірраціональних чисел і т.д. спричинили загальний шок. Проте, ніщо не змусило греків зацікавитися алгеброю й її методами подібно до геометричних. Тому ще на початку дев'ятнадцятого століття багато давніх математичних проблем залишалося нерозв'язаними. Лише дослідження видатних вчених XIX ст. значно розвинули загальну алгебраїчну теорію, що дозволило на новому науковому рівні дослідити нерозв'язані завдання давнини [17].

Подібні «застійні» процеси у позашкільній науково-дослідній діяльності можуть згодом спричинити брак наукових і технічних працівників в галузях, пов'язаних з математичними обчисленнями, що зумовило вибір теми статті.

Mema роботи: дослідити та проаналізувати ефрективність організації позакласної науководослідницької роботи учнів-членів МАН України секції «Математика» для удосконалення вибору тем робіт в аспекті прикладного застосування.

\section{II Матеріал і методи дослідження}

Для розв'язання поставлених завдань використано такі загальнонаукові методи: теоретичний (вивчення й аналіз наукових досліджень, узагальнення інфрормації для визначення теоретикометодологічних основ дослідження, упорядкування досвіду науковців за останні роки для розуміння змісту і проблем науково-дослідницької діяльності учнів); емпіричний метод (опис науково-дослідної роботи учнів за принципом прикладного застосування математичних знань і умінь).

М. Пихтар, проаналізувавши психолого-педагогічну та методичну літературу, вказує на те, що питання про ефективні форми організації позакласної роботи $є$ недостатньо вивченим. Результати діяльності територіальних відділень МАН, досвід роботи окремих педагогів засвідчують існування цілого ряду проблем на шляху вирішення основного завдання - розвитку математичних (творчих математичних) здібностей школярів, однією з яких $€$ відсутність належного дидактичного, навчальнометодичного забезпечення навчально-розвивального процесу в структурі МАН, ефективної, педагогічно збалансованої розвивальної системи [18]. М. Пихтарем на рис. 1 запропоновано модель навчальної діяльності учнів-членів МАН. Водночас, у своїх розвідках дослідник розмежовує поняття навчальнодослідницької діяльності та науково-дослідної діяльності учнів-членів МАН. 


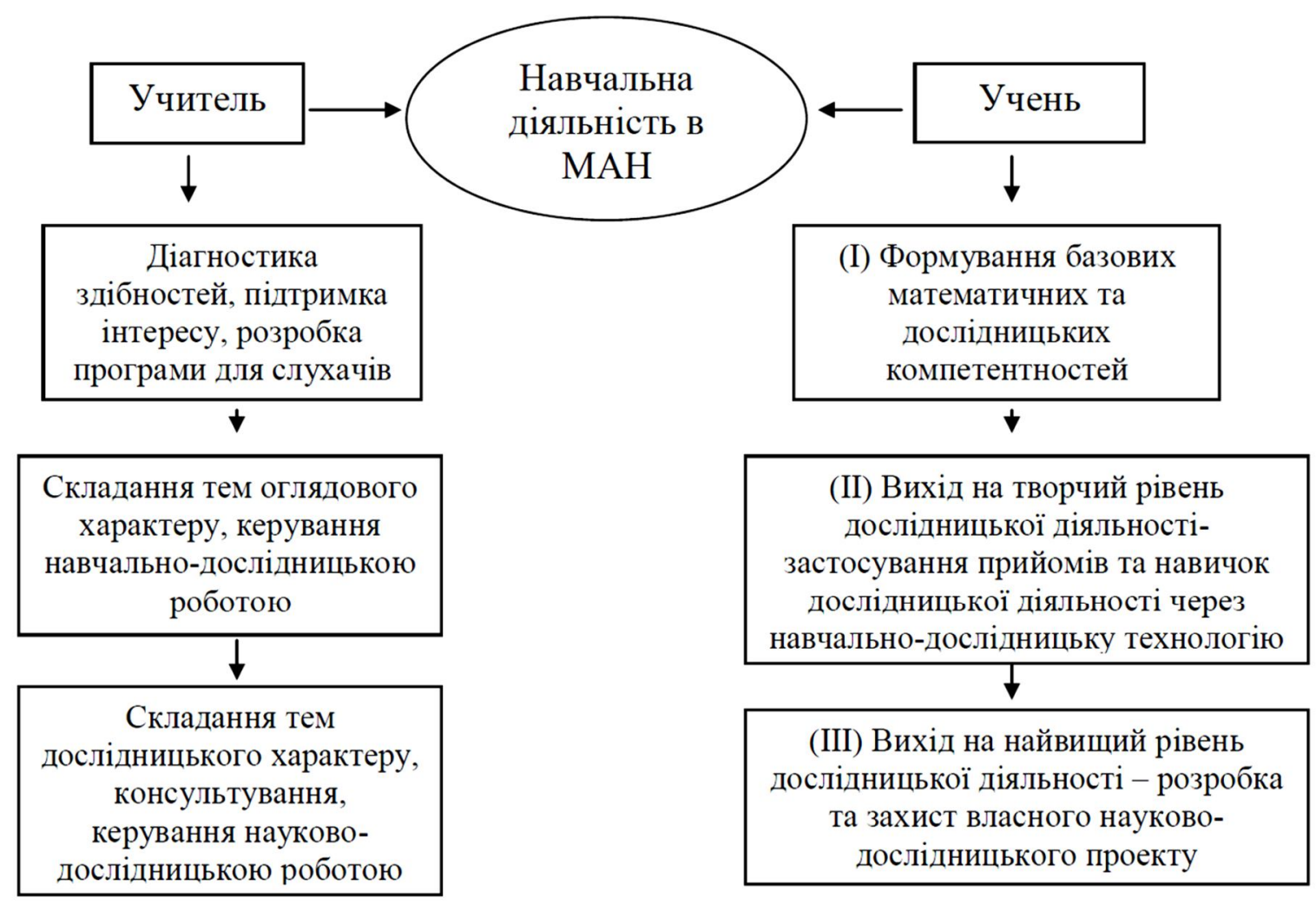

Рис. 1. Схема моделі розвитку математичних та дослідницьких здібностей учнів у рамках МАН (за М. Пихтарем) [18]

Навчально-дослідницька діяльність - це діяльність, головною метою якої є освітній результат, вона направлена на навчання учнів, розвиток у них дослідницького типу мислення. Науково-дослідна діяльність - це вид діяльності, направлений на отримання нових об'єктивних наукових знань [18].

Якщо на перших двох етапах формування базових математичних компетентностей та відповідного рівню дослідницької діяльності зазвичай успішно забезпечує учитель завдяки своїм профресійним компетентностям і здібностям, для вдосконалення вибору тем науково-дослідницьких робіт учнів-членів МАН у бік їхнього прикладного характеру на етапі III пропонуємо залучати стейкхолдерів, або партнерів освіти, - зацікавлених у результатах дослідницьких проектів підприємств, компаній, організацій, осіб, - для підвищення актуальності досліджень, врахування останніх наукових досягнень і виробничих технологій у відповідній галузі. Отже, схему, запропоновану М. Пихтарем, доповнимо блоком, що враховує вплив стейкхолдерів освіти на вибір теми проекту (рис. 2):

Мета побудови подібної моделі - максимізувати позитивний вплив стейкхолдерів освіти на науково-дослідницьку роботу учнів-членів МАН для підвищення результатів на III етапі дослідницької діяльності. Залучення стейкхолдерів до консультування та керування науково-дослідницькою роботою забезпечує системність, цілісність і адекватність рішень під час розробки проектів. Головна умова позитивного впливу - ефективна взаємодія стейкхолдерів з учителем-керівником математичного гуртка МАН на стадії вибору, обґрунтування і складання тем і на усіх стадіях виконання науково-дослідницьких проектів учнів. Така взаємодія математичних компетентностей учителя і професійних компетентностей стейкхолдерів значно підвищить ймовірність успішного застосування результатів проектів.

О. Балакірева і Р. Левін, досліджуючи проблематику стейкхолдерства української освіти, зазначають, що проблеми пов'язані, передусім, з ідеологією підходу до визначення головних стейкхолдерів та розподілення їх ролей. Дослідники звертаються до американського досвіду успішного вирішення проблем математичної підготовки учнів наприкінці XX століття. 2000 року Національною комісією США з викладання математики й природничих наук було створено доклад міністру освіти США щодо поставлених завдань - дослідити причини відставання американських учнів в математиці та природничих науках. 


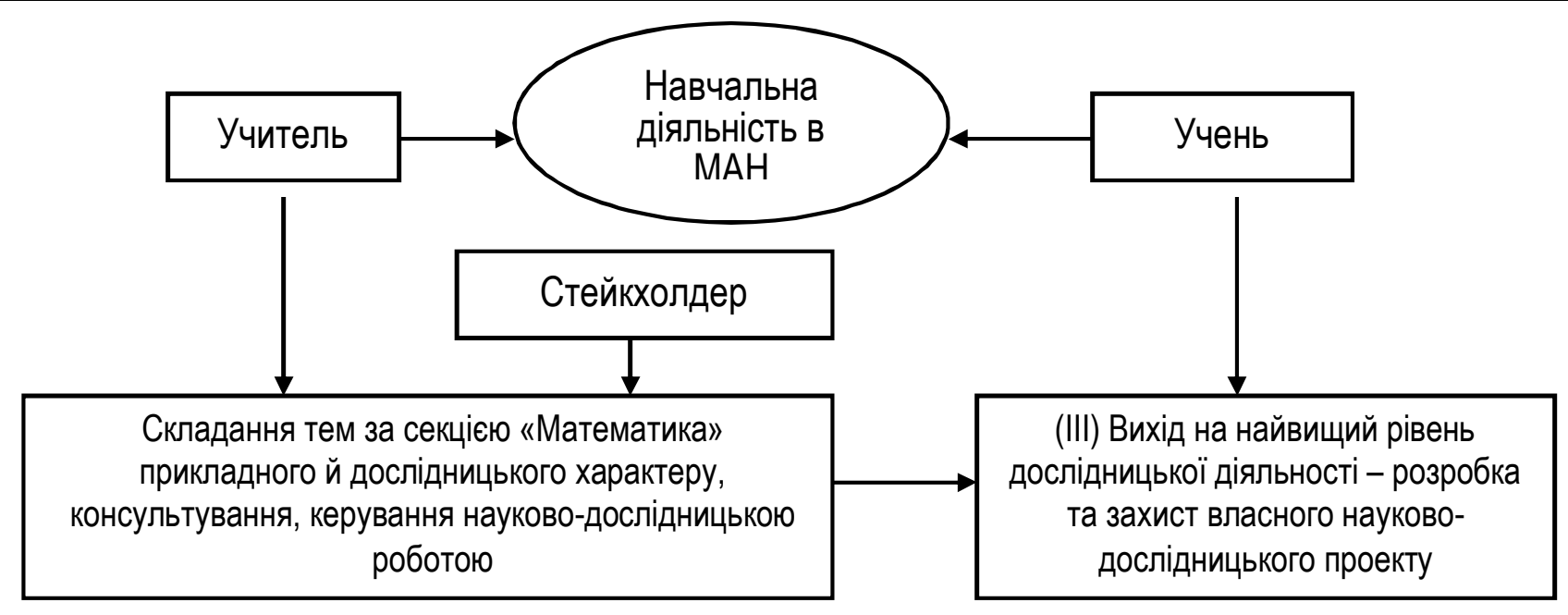

Рис. 2. Удосконалена схема моделі розвитку математичних та дослідницьких здібностей учнів-членів МАН із активним залученням стейкхолдерів

У той час результати міжнародного дослідження якості освіти TIMSS-1999 показали негативну картину зниження рівня освіти, що застаріло на три десятиліття, оскільки американські восьмикласники посіли 18-е і 19-е місця з природничих наук та математики відповідно. У доповіді було визначено сім груп учасників процесу - дійсно, головних стейкхолдерів шкільної освіти: батьки, вчителі, шкільні ради і адміністрації, директори коледжів і шкіл, керівництво штату, вищі навчальні заклади, представники бізнесу, які були охоплені впровадженням 14-ті стратегій, детально прописаних за спрямованістю, функціями, змістом, організацією, заходами, методологією, джерелами фінансування. Було чітко регламентовано, хто і як буде щодня імплементувати стратегії у практику, місцевій владі, бізнесу та університетам були визначені конкретні завдання. Реалізація частини запропонованих у доповіді Національної комісії США з викладання математики й природничих наук заходів дозволила за 12 років (тимчасовий цикл зміни поколінь в американській школі) істотно поліпшити результати освіти: в TIMSS2011 вже були зайняті відповідно 10-е місце з природничих наук і 9-е - 3 математики [4].

\section{III Результати}

Проаналізуємо детальніше зміст науково-дослідницьких робіт учнів-членів МАН відділення математики за 2017-2019 роки [19], [20], [21].

Серед 24 робіт секції «Математика» 2019 року лише дві (8,3\%) мають прикладний характер вони спрямовані на удосконалення розв'язування олімпіадних задач з тієї ж математики [21]. Тож, математика в даному випадку «обслуговує» саму себе. Водночас, кількість тем практичного характеру в секціях «Прикладна математика» і «Математичне моделювання» складає 6 з 24 (25 \%) і 10 з 22 (45,4 \%) робіт, відповідно. Серед тем науково-дослідницьких робіт цих секцій можна виокремити, наприклад, такі: «Математика на футбольному полі», «Формування оптимального інвестиційного портфеля фізичних осіб», «Методи розв'язування транспортних задач», «Чисельний розрахунок частот вільних коливань жорстко закріпленої квадратної пластини», «Моделювання вихрових слідів повітряних суден», «Імітаційне моделювання прогнозування виробництва», «Графи як модель для розв'язування задач складання суміші» [21]. У 2017-2018 рр. прикладна спрямованість тем секції «Математика» також $€$ набагато меншою порівняно із секціями «Прикладна математика» і «Математичне моделювання».

Прикладами науково-дослідницьких робіт учнів-членів МАН, що за своїм змістом передбачають практичне застосування, $€$ теми з конкурсу робіт МАН 2018 року «Застосування на практиці простіших звичайних диференціальних рівнянь» [20] та з конкурсу робіт МАН 2019 року «Теорія графрів та їх застосування в енергозбереженні» [21]. Натомість, присутні теми вкрай широкого формулювання, наприклад, «Комплексні числа в геометрії» [19], «Функціональні рівняння», «нвверсія» [20], «Ортодіагональні трикутники», «Дільники чисел» [21]. Ще більше на конкурс подано вузьких і конкретних тем, що не містять у формулюванні елементів дослідження, тобто слів «вивчення», «порівняння», 
«дослідження», «виявлення». Це, наприклад, такі: «Метод площ», «Сума послідовних чисел Фібоначчі», «Числові послідовності 3 властивістю однорідності», «Ортоцентричний тетраедр. Властивості ортоцентричного тетраедра» [19], «Нерівність Мюрхеда», «Числові конструкції зі степеням», «Сумування послідовностей», «Багатокрокові ігри» [20], «Нерівності в тетраедрі», «Нерівність Карамати», «Вкладені правильні многогранники і екстремуми» [21] та інші.

Отже, за результатами аналізу конкурсних науково-дослідницьких робіт секції «Математика» можна виокремити типові помилки учасників конкурсу МАН у виборі тем і змісті проектів:

- обрана тема є дуже широкою (масштабною), в неї не наведено конкретної наукової проблеми. Надмірне захоплення математичними й статистичними даними має наслідком відступ від теми, адже всі розділи дослідження повинні працювати на розкриття заявленої теми;

- часто учні-члени МАН не виокремлюють у своїй роботі проблему. Робота виграє, якщо автор чітко визначає, де виникають протиріччя. Проблеми з'являються у тому випадку, якщо виникають і формулюються питання, що направляють хід дослідження;

- відсутність загальних висновків або їх невідповідність визначеним завданням дослідження (найпоширені помилки);

- помітно, що на різних етапах роботи учень і його керівник не співвідносять напрацьоване із заявленою темою, не бажають відмовитися від зайвого матеріалу - невідповідного темі проекту.

Проте, значно краще виглядають роботи, в яких наведена актуальність теми дослідження, а також роботи, в яких аналізуються дослідження за даною темою, зроблені раніше.

\section{IV Обговорення}

Підвищення мотивації учнів до прикладного застосування математичних знань і умінь у своїх дослідженнях є предметом інтересу багатьох дослідників.

Так, для розвитку пізнавальної активності учнів під час науково-дослідної діяльності Д. Васильєва пропонує проводити лабораторні роботи на уроках математики й навіть вдома, оскільки такий вид роботи показує прикладне застосування математики й актуалізує знання та вміння учнів, здобуті раніше. Виконання лабораторних робіт вимагає вміння учнів проводити різноманітні вимірювання, визначати невідомі величини з формул, а також обчислювати середнє значення величини та похибки. Обробка результатів вимірювання - також надзвичайно корисне й цікаве завдання для старшокласників. Д. Васильєва наводить приклади декількох лабораторних робіт з вирішення екологічних проблем, які можуть бути проведені учнями самостійно без будь-якого спеціального обладнання. Для учнів-жителів міст пропонується розрахувати, скільки можна зекономити на місяць при сплаті за воду, якщо під час чищення зубів використовувати не проточну воду, а заздалегідь підготовлену в склянці. Як альтернатива для учнів сільських шкіл, які досі опалюють за допомогою котелень, що працюють на вугіллі, пропонується розрахувати витрати кисню під час його спалювання, i дослідити, чи зможе площа зелених насаджень біля школи компенсувати протягом року витрату кисню при спалювані вугілля у шкільній котельні, що знаходиться у приміщенні школи, за один опалювальний сезон. Авторка вважає, що дослідницькі завдання у вигляді запропонованих лабораторних робіт на уроках математики демонструють прикладний аспект математики, спонукають учнів дізнатися більше про екологічні проблеми та обговорити можливі шляхи їх вирішення [16].

Погляд Д. Васильєвої на екологізацію математичної освіти учнів поділяє й І. Хівріч, яка наполягає на розв'язуванні математичних задач екологічного змісту для недопущення в майбутньому помилок, пов'язаних з непродуманим натиском на природу. Як і в екології, в математиці існують два основних джерела наукових відкриттів: практика та потреба систематизації знайдених фактів, їх аналіз, систематизація, з'ясування їх взаємозв'язку. Математика створює умови для розвитку вміння давати кількісну оцінку стану природних об'єктів і явищ, позитивних і негативних наслідків діяльності людини в природному і соціальному оточенні. На уроках математики слід добирати систему задач, яка розкриває питання: споживання води в Україні, значення рослин у житті людини, скорочення лісових ресурсів та його наслідки, значення тварин у природі та в житті людини тощо. Під час добору задач доцільно дотримуватися певних вимог. Задача має демонструвати практичне застосування математичних ідей і методів та ілюструвати матеріал, що викладається на певному уроці, містити 
відповідні або інтуїтивно зрозумілі учням поняття і терміни, а також реальні числові дані, що не ведуть до громіздких обчислень [2].

На думку М. Штольмана (M. Stohlmann), математика не отримала достатньої уваги серед учнів. Це може бути частково пов'язане з тим, що учителі математики не впевнені в тому, як реалізувати інтегроване навчання математики в своїх класах. Дослідник пропонує три метода, які учителі математики можуть використати для інтеграції математики з іншими предметами та підвищення дослідної мотивації учнів. Зосередивши увагу на невирішених проблемах завдяки інженерному проектуванню, математичному моделюванню і математиці, інтегрованої з технологією, учні середньої школи ймовірніше будуть сприймати математику як актуальну і цінну науку [5].

\section{V Висновки}

Проблема вибору теми науково-дослідницької роботи учнів-членів МАН є дуже значною. Тема відправна точка дослідницької діяльності, вона пов'язує пізнавальний інтерес і мотиви учня, проблему дослідження і зміст роботи. Формулювання теми дослідження має бути доступним, цікавим, корисним для учнів-членів МАН. Вибір теми є складним етапом одночасно для учителів-керівників робіт і для учнів. Під час вибору теми педагог-математик може керуватися різними підставами, пов'язаними з тим, які результати йому на даний момент потрібні: предметні (тема дослідження в рамках окремих підрозділів математики), загальнонаукові (тема забезпечує формування дослідницьких умінь) або особистісні (тема пов'язана із певними соціальними проблемами).

Для запобігання однобічного (суб'єктивного) підходу до вибору тем рекомендується, окрім учителів та учнів, залучати до процесу підготовки науково-дослідницьких проектів стейкхолдерів освіти, зацікавлених, по-перше, у прикладному змісті тем, а по-друге - у результатах, які б мали практичне застосування й значення.

Отже, тема науково-дослідної роботи з математики, що висувається на конкурс МАН, має бути не надзвичайно складною, ґрунтуватися на наявних розробках і напрацюваннях науковців. Тема проекту для захисту має бути цікавою одночасно учневі й учителеві-керівнику, для якіснішого дослідження краще вибирати вузьку, а не масштабну тему, не рекомендується брати теми глобальні, добре вивчені й такі, що вже подавалися учнями-членами МАН на попередніх конкурсах.

\section{Бібліографічні посилання}

1. Грицюк О. С. Сучасний стан і перспективи впровадження STEM-освіти в Україні. Інженерні та освітні технології. 2017. № 3 (19). C. 163-168. URL: http://eetecs.kdu.edu.ua/2017_03/EETECS2017_0324.pdf. (дата звернення: 27.08.2019).

2. ХіврічІ.В. Роль математики в екологічному вихованні людини. Неперервна освіта для сталого розвитку: фрілософсько-теоретичні контексти та педагогічна практика: матеріали Всеукраїнської наук.-практ. конф. (Дніпро, 06 грудня 2018 року), частина ІІ. Дніпро: СПД «Охотнік», 2019. С. 85-87.

3. Шидакова-Каменюка О. Г., Самохвалова О. В., Олійник С. Г., Кравченко О.І. Методологія та організація наукових досліджень: навч. посібник. Харків: ХДУХТ, 2016. 187 с.

4. Балакирева О. Н., Левин Р. Я. Стейкхолдеры образования - субъекты и роли. Взаимодействие образовательных учреждений со стейкхолдерами: веление времени: матеріали XV Міжнар. наук.-практ. конф. (Харків, 16 лютого 2017 року). Харків: Народна українська академія, 2017. C. 21-27. URL: http://www.nua.kharkov.ua/images/stories/Nauka/Konferenciya/fevral\%202017.pdf. (дата звернення: 02.09.2019).

5. Stohlmann M. Three modes of STEM integration for middle school mathematics teachers. School Science and Mathematics. 2019. Vol. 119, Iss. 5. P. 287-296. DOl: https://doi.org/10.1111/ssm.12339

6. Mohd Rustam R., Azlina K. Challenges in mathematics learning: a study from school students' perspective. URL: https://www.researchgate.net/publication/321873178_Challenges_in_Mathematics_Learning_A_Study_from_School_Student's _Perspective. (дата звернення: 05.09.2019).

7. Jensen F., Sjaastad J. A Norwegian Out-of-School Mathematics Project's Influence on Secondary Students' STEM Motivation. International Journal of Science and Mathematics Education. 2013. Vol.11, Iss. 6. P. 1437-1461. DOI: https://doi.org/10.1007/s10763-013-9401-4

8. Leung A. Exploring STEM Pedagogy in the Mathematics Classroom: a Tool-Based Experiment Lesson on Estimation. International Journal of Science and Mathematics Education. 2019. Vol. 17, Iss. 7. P. 1339-1358. DOI: https://doi.org/10.1007/s10763-018-9924-9

9. Weinberg A., McMeeking L. Toward Meaningful Interdisciplinary Education: High School Teachers' Views of Mathematics and Science Integration. School Science and Mathematics. 2017. Vol.117, Iss. 5. P. 204-213. DOI: https://doi.org/10.1111/ssm.12224 
10. Yu K.-Ch., Wu P.-H., Fan S.-Ch. Structural Relationships among High School Students' Scientific Knowledge, Critical Thinking, Engineering Design Process, and Design Product. International Journal of Science and Mathematics Education. 2019. P. 1-22. DOI: https://doi.org/10.1007/s10763-019-10007-2

11. Bicer A., Capraro R. Mathematics achievement in the secondary high school context of STEM and non-STEM schools. School Science and Mathematics. 2019. Vol. 119, Iss. 2. P. 61-71. DOl: https://doi.org/10.1111/ssm.12321

12. Ling Koh J. H. Articulating Teachers' Creation of Technological Pedagogical Mathematical Knowledge (TPMK) for Supporting Mathematical Inquiry with Authentic Problems. International Journal of Science and Mathematics Education. 2019. Vol. 17, Iss. 6. P. 1195-1212. DOl: https://doi.org/10.1007/s10763-018-9914-y

13. Tas Y., Aksoy G., Cengiz E. Effectiveness of Design-Based Science on Students' Learning in Electrical Energy and Metacognitive Self-Regulation. International Journal of Science and Mathematics Education. 2019. Vol. 17, Iss. 6. P. 11091128. DOI: https://doi.org/10.1007/s10763-018-9923-x

14. Sinicrope R., Eppler M., Preston R., Ironsmith M. Preservice Teachers of High School Mathematics: Success, Failure, and Persistence in the Face of Mathematical Challenges. School Science and Mathematics. 2015. Vol. 115, Iss. 2. P. 56-65. DOI: https://doi.org/10.1111/ssm.12104

15. Polly D., Mraz M., Algozzine R. Implications for Developing and Researching Elementary School Mathematics Coaches. School Science and Mathematics. 2013. Vol. 113, Iss. 6. P. 297-307. DOl: https://doi.org/10.1111/ssm.12029

16. Васильєва Д. В. Науково-дослідницька діяльність учнів в умовах реалізації компетентнісного підходу до навчання математики. Педагогічні науки: теорія, історія, інноваційні технології. 2016. № 2 (56). C. 196-202. URL: http://library.sspu.sumy.ua/wp-content/uploads/2018/04/2_16.pdf. (дата звернення: 02.09.2019).

17. Добровольска І. 3 досвіду роботи у Малій академії наук. Школа Юного Вченого: науково-популярний журнал МАН. 2009. № 1-2. URL: http://scientistschool.org.ua/?p=52. (дата звернення: 03.09.2019).

18. Пихтар М. П. Модель системи розвитку математичних здібностей школярів у діяльності Малої академії наук. Науковий часопис Національного педагогічного університету імені М. П. Драгоманова. Серія 3 : Фізика і математика у вищій $і$ середній школі. 2013. Вип. 11. С. 71-80. URL: http://enpuir.npu.edu.ua/bitstream/123456789/15490/1/Pikhtar.pdf. (дата звернення: 27.08.2019).

19. Протокол захисту науково-дослідницьких робіт учнів-членів MAH України у 2017 році. Секція: математики. URL: http://man.gov.ua/upload/konkurs-zahyst/2017/Results/mathematics/Zah/Matemat_zah.pdf. (дата звернення: 23.08.2019).

20. Протокол захисту науково-дослідницьких робіт учнів-членів MAH України у 2018 році. Секція: математики. URL: http://man.gov.ua/upload/konkurs-zahyst/2018/Results/mathematics/Zah/Matemat_zah.pdf. (дата звернення: 23.08.2019).

21. Збірка матеріалів III етапу Всеукраїнського конкурсу-захисту науково-дослідницьких робіт учнів-членів Малої академії наук України у 2019 році. К.: Національний центр «Мала академія наук України», 2019. 146 c. URL: https://mon.gov.ua/storage/app/media/news/Новини/2019/05/06/-06-05-19.pdf. (дата звернення: 23.08.2019).

\section{References}

1. Grytsiuk, O. S. (2017). Suchasnyy stan i perspektyvy vprovadzhennya STEM-osvity v Ukrayini, Engineering and Educational Technologies, 3(19), 163-168. URL: http://eetecs.kdu.edu.ua/2017_03/EETECS2017_0324.pdf. (accessed: 27.08.2019). [in Ukrainian]

2. Khivrich, I. V. (2019). Rol' matematyky v ekolohichnomu vykhovanni lyudyny, Neperervna osvita dlya staloho rozvytku: filosofs ko-teoretychni konteksty ta pedahohichna praktyka: materialy Vseukrayins koyi nauk.-prakt. konf. (Dnipro, 06 hrud. 2018 r.), part II, SPD «Okhotnik», Dnipro, Ukraine, 85-87. [in Ukrainian]

3. Shydakova-Kamenyuka, O. H., Samokhvalova, O. V., Oliynyk, S. H., \& Kravchenko, O. I. (2016). Metodolohiya ta orhanizatsiya naukovykh doslidzhen', KHDUKHT, Kharkiv, Ukraine, 187 p. [in Ukrainian]

4. Balakyreva, O. N., Levyn, R. Ya. (2017). Steykkholdery obrazovanyya - sub'ekty y roly, Vzaymodeystvye obrazovatel'nykh uchrezhdenyy so steykkholderamy: velenye vremeny: materialy XV Mizhnar. nauk.-prakt. konf. (Kharkiv, 16 lyutoho 2017 roku), Narodna ukrayins'ka akademiya, Kharkiv, Ukraine, 21-27. URL: http://www.nua.kharkov.ua/images/stories/Nauka/Konferenciya/fevral\%202017.pdf. (accessed: 02.09.2019). [in Russian]

5. Stohlmann, M. (2019). Three modes of STEM integration for middle school mathematics teachers, School Science and Mathematics, 119(5), 287-296. DOl: https://doi.org/10.1111/ssm.12339

6. Mohd Rustam, R., Azlina, K. (2016). Challenges in mathematics learning: a study from school students' perspective. URL: https://www.researchgate.net/publication/321873178_Challenges_in_Mathematics_Learning_A_Study_from_School_Student's Perspective. (accessed: 05.09.2019).

7. Jensen, F., Sjaastad, J. (2013). A Norwegian Out-of-School Mathematics Project's Influence on Secondary Students' STEM Motivation, International Journal of Science and Mathematics Education, 11(6), 1437-1461. DOI: https://doi.org/10.1007/s10763-013-9401-4

8. Leung, A. (2019). Exploring STEM Pedagogy in the Mathematics Classroom: a Tool-Based Experiment Lesson on Estimation, International Journal of Science and Mathematics Education, 17(7), 1339-1358. DOI: https://doi.org/10.1007/s10763-018-9924-9

9. Weinberg, A., McMeeking, L. (2017). Toward Meaningful Interdisciplinary Education: High School Teachers' Views of Mathematics and Science Integration, School Science and Mathematics, 117(5), 204-213. DOI: https://doi.org/10.1111/ssm.12224 
10. Yu, K.-Ch., Wu, P.-H., \& Fan, S.-Ch. (2019). Structural Relationships among High School Students' Scientific Knowledge, Critical Thinking, Engineering Design Process, and Design Product, International Journal of Science and Mathematics Education, 1-22. DOI: https://doi.org/10.1007/s10763-019-10007-2

11. Bicer, A., Capraro, R. (2019). Mathematics achievement in the secondary high school context of STEM and non-STEM schools, School Science and Mathematics, 119(2), 61-71. DOl: https://doi.org/10.1111/ssm.12321

12. Ling Koh, J. H. (2019). Articulating Teachers' Creation of Technological Pedagogical Mathematical Knowledge (TPMK) for Supporting Mathematical Inquiry with Authentic Problems, International Journal of Science and Mathematics Education, 17(6), 1195-1212. DOI: https://doi.org/10.1007/s10763-018-9914-y

13. Tas, Y., Aksoy, G., Cengiz, E. (2019). Effectiveness of Design-Based Science on Students' Learning in Electrical Energy and Metacognitive Self-Regulation, International Journal of Science and Mathematics Education, 17(6), 1109-1128. DOI: https://doi.org/10.1007/s10763-018-9923-x

14. Sinicrope, R., Eppler, M., Preston, R., \& Ironsmith, M. (2015). Preservice Teachers of High School Mathematics: Success, Failure, and Persistence in the Face of Mathematical Challenges, School Science and Mathematics, 115(2), 56-65. DOI: https://doi.org/10.1111/ssm.12104

15. Polly, D., Mraz, M., Algozzine, R. (2013). Implications for Developing and Researching Elementary School Mathematics Coaches, School Science and Mathematics, 113(6), 297-307. DOl: https://doi.org/10.1111/ssm.12029

16. Vasyl'yeva, D. V. (2016). Naukovo-doslidnyts'ka diyal'nist' uchniv v umovakh realizatsiyi kompetentnisnoho pidkhodu do navchannya matematyky, Pedahohichni nauky: teoriya, istoriya, innovatsiyni tekhnolohiyi, 2(56), 196-202. URL: http://library.sspu.sumy.ua/wp-content/uploads/2018/04/2_16.pdf. (accessed: 02.09.2019). [in Ukrainian]

17. Dobrovol'ska, I. (2009). Z dosvidu roboty u Maliy akademiyi nauk, Shkola Yunoho Vchenoho: naukovo-populyarnyy zhurnal MAN, 1-2. URL: http://scientistschool.org.ua/?p=52. (accessed: 03.09.2019). [in Ukrainian]

18. Pykhtar, M. P. (2013). Model' systemy rozvytku matematychnykh zdibnostey shkolyariv u diyal'nosti Maloyi akademiyi nauk, Naukovyy chasopys Natsional 'noho pedahohichnoho universytetu imeni M. P. Drahomanova. Seriya 3 : Fizyka i matematyka u vyshchiy i seredniy shkoli, 11, 71-80. URL: http://enpuir.npu.edu.ua/bitstream/123456789/15490/1/Pikhtar.pdf. (accessed: 27.08.2019). [in Ukrainian]

19. Protokol zakhystu naukovo-doslidnyts'kykh robit uchniv-chleniv MAN Ukrayiny u 2017 rotsi. Sektsiya: matematyky. (2017). URL: http://man.gov.ua/upload/konkurs-zahyst/2017/Results/mathematics/Zah/Matemat_zah.pdf. (accessed: 23.08.2019). [in Ukrainian]

20. Protokol zakhystu naukovo-doslidnyts'kykh robit uchniv-chleniv MAN Ukrayiny u 2018 rotsi. Sektsiya: matematyky. (2018). URL: http://man.gov.ua/upload/konkurs-zahyst/2018/Results/mathematics/Zah/Matemat_zah.pdf. (accessed: 23.08.2019). [in Ukrainian]

21. Zbirka materialiv III etapu Vseukrayins'koho konkursu-zakhystu naukovo-doslidnyts'kykh robit uchniv-chleniv Maloyi akademiyi nauk Ukrayiny u 2019 rotsi. (2019). Natsional'nyy tsentr «Mala akademiya nauk Ukrayiny», Kyiv, Ukraine, 146 p. URL: https://mon.gov.ua/storage/app/media/news/Новини/2019/05/06/-06-05-19.pdf. (accessed: 23.08.2019). [in Ukrainian]

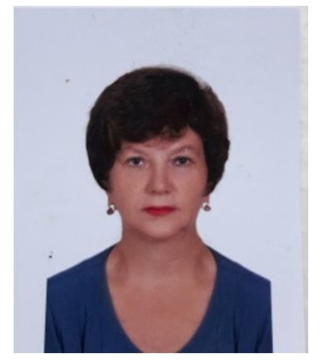

Скотнікова Людмила Миколаївна,

Старший викладач кафедри інформатики і вищої математики,

Кременчуцький національний університет імені Михайла Остроградського,

адреса. вул. Першотравнева, 20, м. Кременчук, Україна, 39600

Тел. (05366) 3-00-50. E-mail: Iskotnikova7@gmail.com

\section{Skotnikova Ludmyla Mykolaivna,}

Senior lecturer of Mathematics and Computer Science Department

Kremenchuk Mykhailo Ostrohradskyi National University,

Pershotravneva st, 20, Kremenchuk, Ukraine, 39600

Tel. +38(05366) 30050. E-mail: Iskotnikova7@gmail.com

ORCID: 0000-0001-6470-3280

Citation (APA):

Skotnikova L. (2019). Choice of mathematics research papers themes by senior high school students-members of MAS in application aspect. Engineering and Educational Technologies, 7 (4), 22-30. doi: https://doi.org/10.30929/2307-9770.2019.07.04.02

\section{Цитування (ДСТУ 8302:2015):}

Скотнікова Л. М. Вибір тем науково-дослідницьких робіт з математики учнями-членами МАН в аспекті прикладного застосування / Інженерні та освітні технології. 2019. Т. 7. № 4. С. 22-30. doi: https://doi.org/10.30929/2307-9770.2019.07.04.02

Обсяг статmі: сторінок - 9 ; умовних друк. аркушів - 1,304. 